\title{
Fire resistance of lightweight steel-concrete slab panels under high-temperature exposure
}

\author{
Vladimir Rybakov ${ }^{1 *[0000-0002-2299-3096]}$, Anatoly Seliverstov ${ }^{2}$, and Oybek Vakhidov ${ }^{3}$ \\ ${ }^{1}$ Peter the Great St. Petersburg Polytechnic University, 195251, Saint-Petersburg, Russia \\ ${ }^{2}$ Sovbi, Ltd, Ispolkomskaya st., 4-6, letter A, room 4H, office 1, 191024, Saint-Petersburg, Russia \\ ${ }^{3}$ Tashkent Institute of Irrigation and Agricultural Mechanization Engineers, Tashkent, Uzbekistan
}

\begin{abstract}
Lightweight steel concrete structures (LSCS) - an innovative energy-efficient building structure type that can be used both as loadbearing and as enclosing one. They consist of profiled steel - usually galvanized and cold-bent - filled with a monolithic foam concrete with a $400 \mathrm{~kg} / \mathrm{m}^{3}$ density and with fiber cement sheets sheathing. These structures can be used in industrial and civil buildings as internal and external bearing and enclosing wall structures and as slabs, energy-efficient roof covering. According to the LSCS production method, prefabricated panels (walls and slabs) and building site performed constructions are distinguished. The paper presents the testing results with the aim to determine the fire resistance limit of a slab panel fragment by bearing capacity (R), loss of integrity (E), loss of heat insulating capability (I) and fire hazard class. Two samples of a slab panel fragment were selected for the fire resistance high-temperature tests. The actual fire resistance limit of samples of the slab panel fragment is at least REI 60 with a uniformly distributed load 4 $\mathrm{kN} / \mathrm{m}^{2}$.
\end{abstract}

\section{Introduction}

Lightweight steel-concrete slab panels are the type of lightweight steel concrete structures (LSCS, [1-2]). They are well-known as energy-efficient composite steel and concrete structures in which as filling concrete monolithic (pouring) foam concrete of the D400...D1000 grade acts; as a rule, LGSS (light gauge steel structures, [3],[4] and etc.) act as profile steel, and permanent formwork functions performing fiber cement panels. The design forces from all loadings are also perceived by foam concrete and profile steel. Similar structures with rolled sections can also be classified as LSCS.

Foam concrete is produced both in a factory and on a construction site, usually has a density of $400 \ldots 600 \mathrm{~kg} / \mathrm{m}^{3}$ for slabs and is used in the innovative building structures type lightweight steel concrete structures (LSCS). Diatomite, microsilica, granite, perlite and vermiculite are used in foam concrete production [5].

In scientific articles [6-9] and etc, other additives are known that are used in lightweight concrete and affect their performance.

*Corresponding author: fishermanoff@mail.ru 
The effect of temperature loss in the enclosing structures linear elements is presented in the article [10].

In [11-13], the behaviour of the reinforced concrete slab during fire exposure was considered, and fire resistance calculations were described.

It is known and proved that prefabricated and monolithic lightweight concretes are usually fire-resistant materials that can withstand increased temperature effects [14-16].

For example, in [17] experimental study of the post-fire mechanical performance of six simply-supported composite slabs after exposure to hydrocarbon fire heating with a maximum temperature of $700^{\circ} \mathrm{C}$ and duration time of $90 \mathrm{~min}$ was conducted. The results show that the overall collapse of the composite slabs will not take place even when there is serious torsion of thin-walled steel beam and more than one serious crack in the concrete, and the maximum deflection of the slabs is less than $\mathrm{L} / 400$ for bearing the uniform load of $2 \mathrm{kN} / \mathrm{m}^{2}$; The ultimate load of the composite slab specimens after fire for which the commonly used nails are set is $14.2 \%$ greater than that with the shear keys made with thinwalled steel plate.

In [18] a new composite panel system based on external insulation has been developed for light gauge steel framing floors to provide a higher fire resistance rating under fire conditions. This article presents the details of an experimental investigation of light gauge steel framing floors made of both the conventional (with and without cavity insulation) and the new composite panel systems under standard fires. Analysis of the fire test results showed that the thermal and structural performance of externally insulated light gauge steel framing floor system was superior to conventional light gauge steel framing floors with or without cavity insulation.

Many other scientific articles [19-24] are devoted to the work of floors at elevated temperatures

In one of our previous works [1] we investigated the load-bearing capacity of an LSCSslab panel under the action of a static load at normal operating ambient temperatures, where the value of $10.71 \ldots 17.53 \mathrm{kN} / \mathrm{m}^{2}$ was experimentally revealed, a similar task under the condition of fire impact was not solved.

Therefore, the purpose of this work is to determine the fire resistance limit of the slab panels made of LSCS under fire action.

Research objectives:

1)Determination of the actual limit of the effective fire resistance of the slab for a standard load of $4 \mathrm{kN} / \mathrm{m}^{2}$.

2)Determination of the temperature gradient along with the thickness of the slab (temperature on the unheated surface)

3)Determination of the deformability of the slab under fire action.

\section{Materials and Methods}

The experimental setup is shown in figure 2. The panel based on LSCS (figure 1) with dimensions 4000x800x216 (mm) has special hinge supports with the rigid plate to avoid local pushing of the panel. 


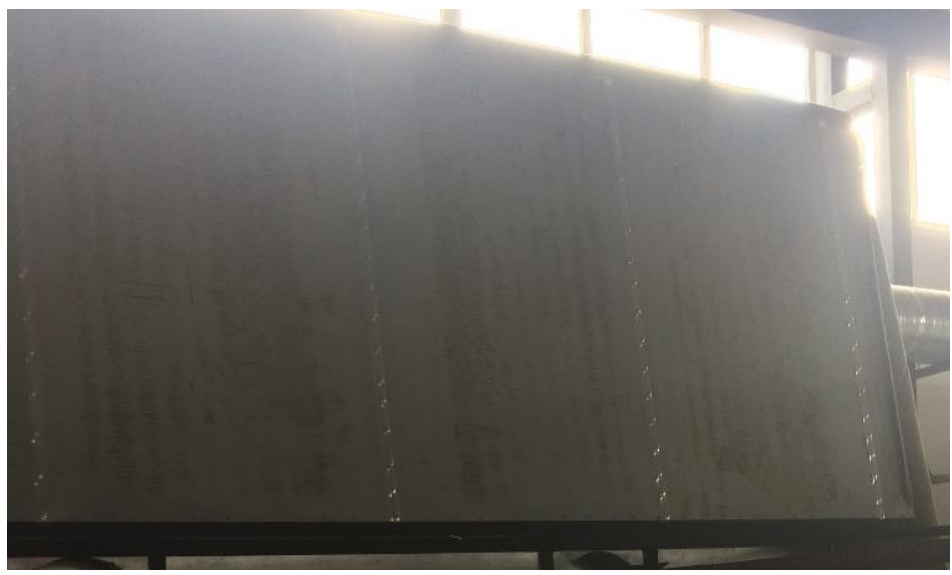

Fig. 1. Appearance of the sample before testing (in vertical position)

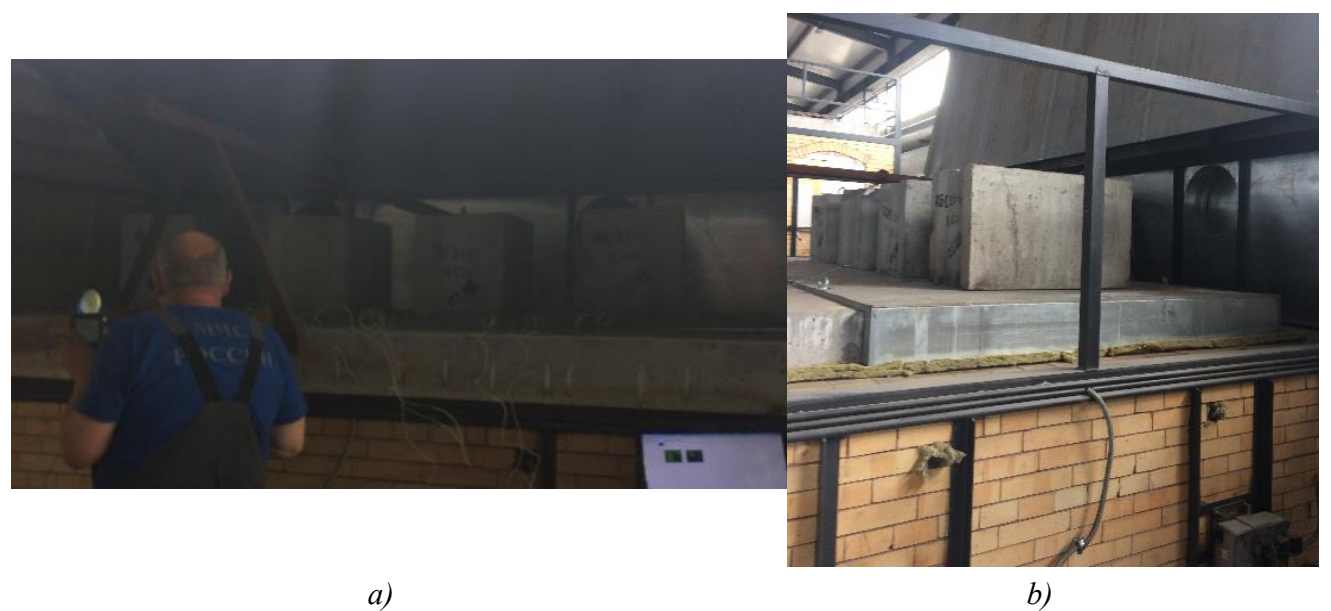

Fig. 2. Type of experimental setup as: (a) front view Description 1; (b) side view.

Loading is being applied with four concrete blocks connected in the uniform system maintaining equality of efforts in each of them. To correspond to the load in the experimental installation to uniformly distributed under each block, distribution elements are installed so that each lack transmits two strip (perpendicular to the span) loads to the panel, which together corresponds to a conventional beam with 4 concentrated loads located at an equal distance from each other.

Measurement of displacements is made using deflection indicators T1, T2 and T3, located in the middle of the span of the slab - on both sides and in the middle between them. 

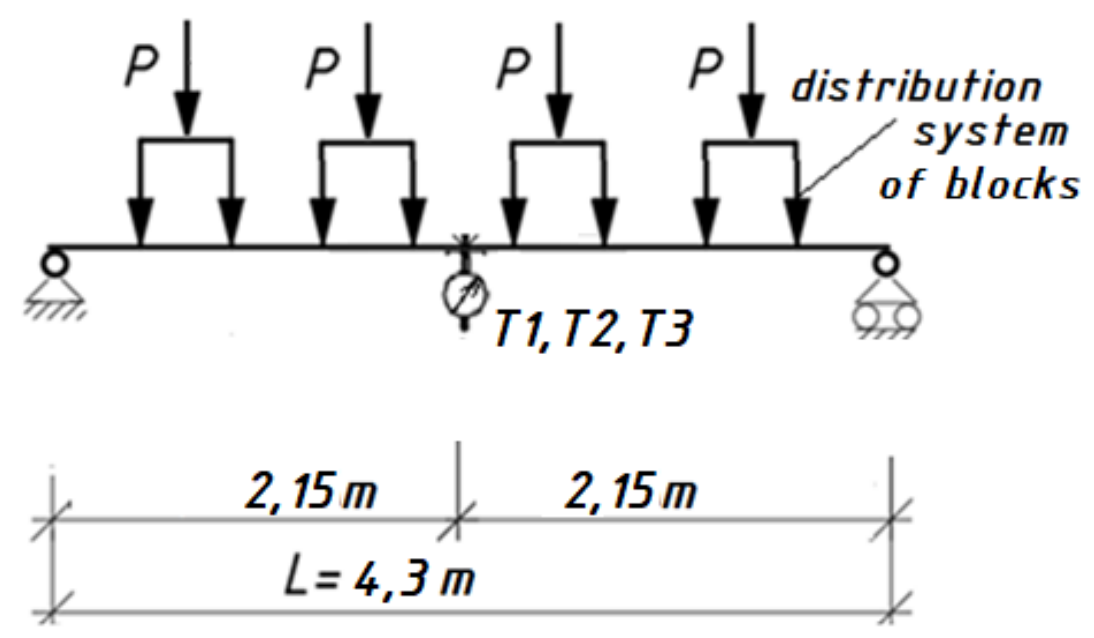

Fig. 3. Test scheme

Thus, the load generated by the equipment is close to uniformly distributed from the point of view of structural mechanics (Figure 3).

Testing was carried out to determine the fire resistance limit of a slab panel fragment by bearing capacity (R), loss of integrity (E), loss of heat insulating capability (I) and fire hazard class.

Two samples of a slab panel fragment were produced for the fire resistance tests.

The appearance of one of the sample before testing is shown in the figure 1. Panel fragment drawing is presented in figure 4. Technical document for panels: STO $06041112-$ 2018. «Panels made of steel-concrete structures based on heat-insulating non-autoclaved monolithic foam concrete, profile steel with fiber-cement sheets covering» (Russian Standard)

GPN is the channel thin-walled profile with the height of the web equal to $204 \mathrm{~mm}$. GPS is the $\mathrm{C}$-shaped thin-walled profile with flanges with the height of the edge equal to $200 \mathrm{~mm}$.

The test method was applied according to GOST 30247.1-94 «Elements of building constructions. Fire-resistance test methods. Loadbearing and separating constructions» (Russian Standard). 

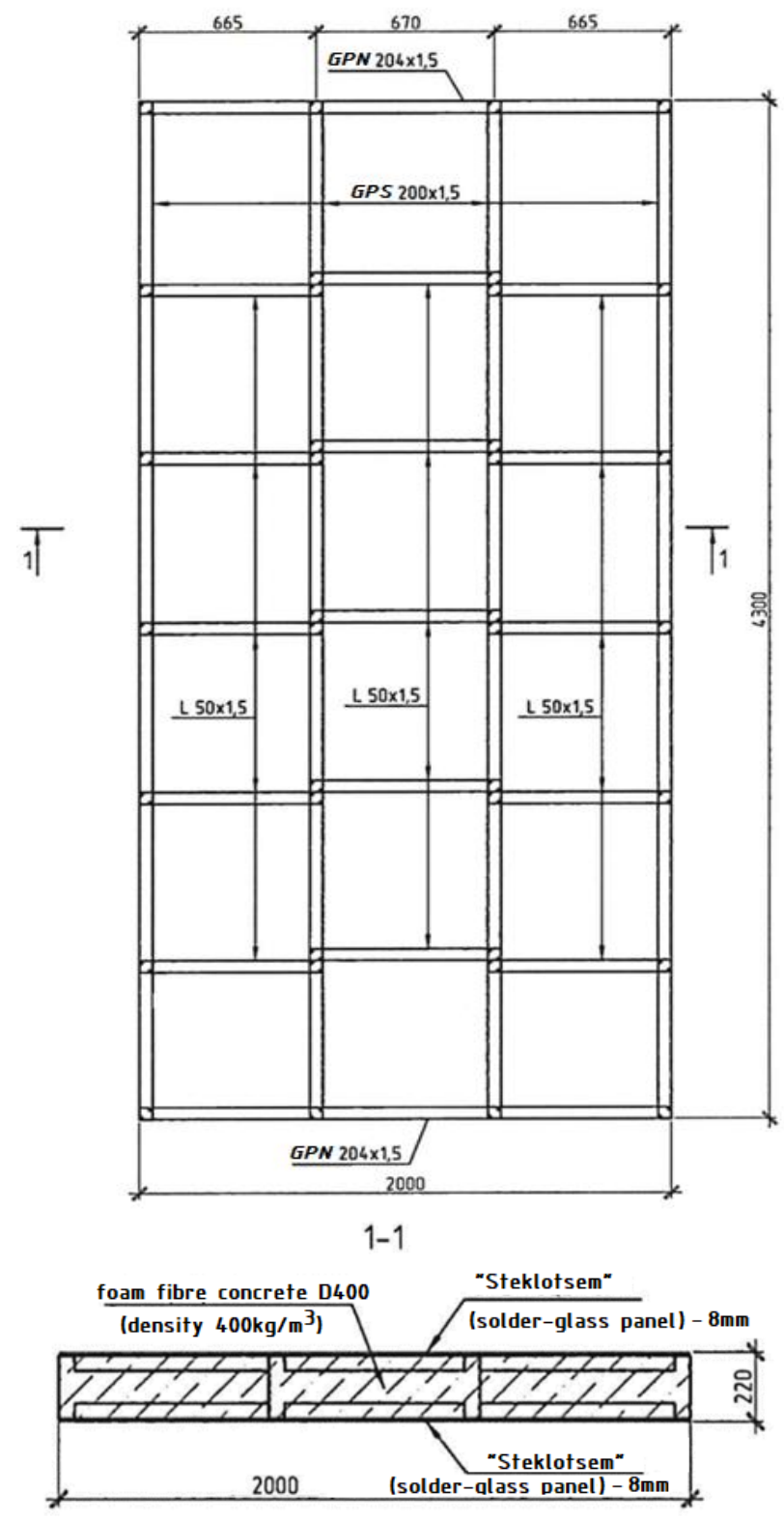

Fig. 4. Panel fragment drawing

In summary, the test method aims to determine time from the beginning of thermal action on the structure until one or several limit states on fire resistance occur subsequently, taking into account the functional purpose of the structure.

\section{Results and Discussion}

The following specimen installations were used for the test. 
A sample of a fragment of the slab panel was installed unbraced horizontally on the opening of the fire oven. The sample scrubbing was performed on two sides. The evenly distributed load during testing was $4 \mathrm{kN} / \mathrm{m}^{2}$.

During the tests, the temperature in the furnace fire chamber was kept constant following the requirements of GOST 30247.0-94. Excessive pressure in the fire chamber of the furnace 5 minutes after the test start at a level of $3 / 4$ of the sample height was maintained within $(10 \pm 2) \mathrm{Pa}$. The fire action on the samples is from below.

The test duration is 60 minutes.

During the tests, the following test results and Observations were obtained.

Specimen 1.

$0 \div 60 \mathrm{~min}$ - changes in appearance, integrity, and heat-insulating ability of the sample were not registered; maximum deflection to the heated side was $88.4 \mathrm{~mm}$. The experiment was terminated after the declared fire resistance limit was reached.

Specimen 2.

$0 \div 60 \mathrm{~min}$ - changes in appearance, integrity, and heat-insulating ability of the sample were not registered; maximum deflection to the heated side was $91.2 \mathrm{~mm}$. The experiment was terminated after the declared fire resistance limit was reached.

Change of average temperature measured in the fire chamber of the furnace is shown in Figures 5, 6; change of average temperature measured on the unheated surfaces of the samples during testing are presented in tables 1,2

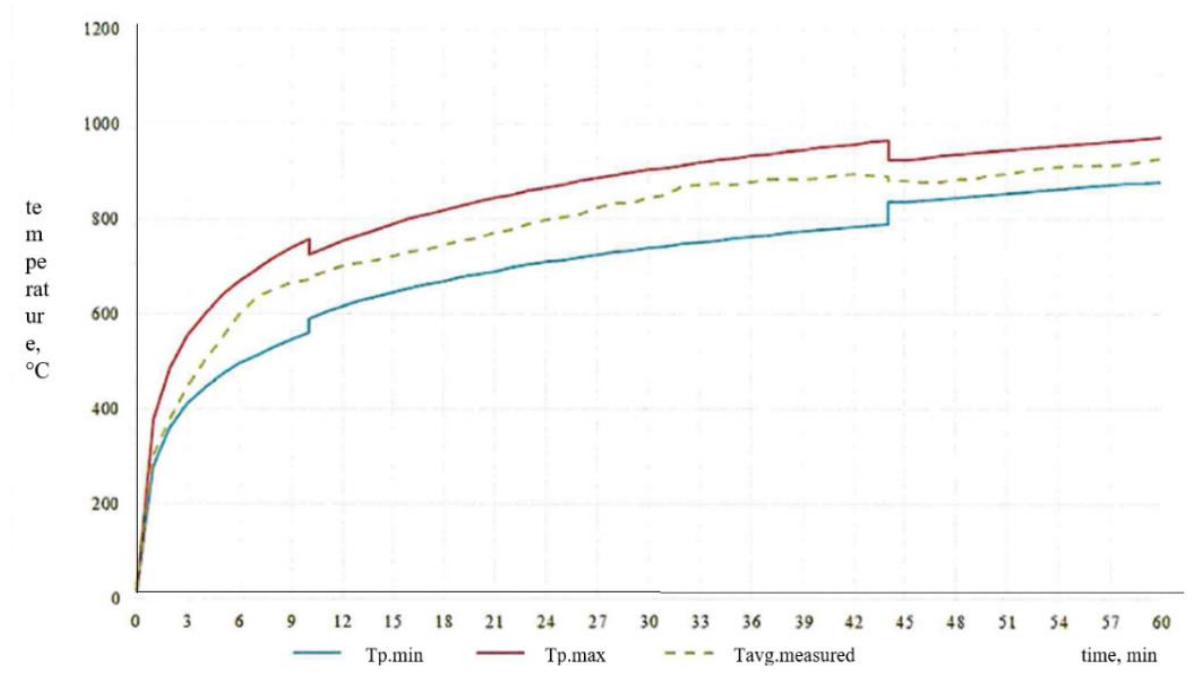

Fig. 5. Temperature change in the fire chamber of the furnace during testing of sample №1: $T_{p . m i n}-$ minimum permissible furnace temperature; $T_{p \cdot \max }$ - maximum permissible furnace temperature; $T_{a v g}$. measured - average measured temperature in the fire chamber of the furnace when testing the sample. 


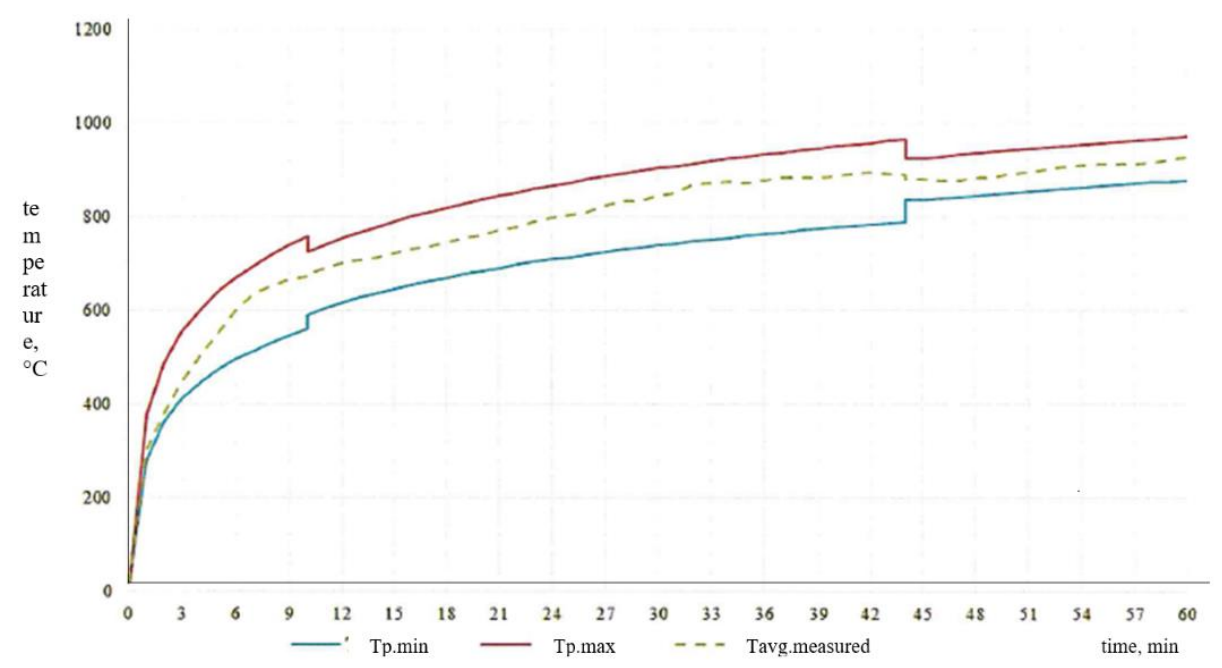

Fig. 6. Temperature change in the fire chamber of the furnace during testing of sample №2: $T_{\text {p.min }}-$ minimum permissible furnace temperature; $T_{\text {p.max }}$ - maximum permissible furnace temperature; Tavg. measured - average measured temperature in the fire chamber of the furnace when testing the sample.

Table 1. Temperature on the non-exposed side of the sample № 1

\begin{tabular}{|c|c|c|c|c|c|c|}
\hline \multirow{2}{*}{$\begin{array}{c}\text { Time, } \\
\text { min }\end{array}$} & \multicolumn{6}{|c|}{ Temperature according to thermoelectric converters on the non- } \\
& \multicolumn{7}{|c|}{ exposed side of the sample №1, ${ }^{\circ} \mathrm{C}$} \\
\hline & TP №1 & TP №2 & TP №3 & TP №4 & TP №5 & T avg. \\
\hline 0 & 20 & 21 & 21 & 21 & 22 & 21 \\
\hline 5 & 20 & 21 & 21 & 21 & 23 & 21 \\
\hline 10 & 20 & 21 & 21 & 22 & 23 & 21 \\
\hline 15 & 21 & 22 & 22 & 23 & 24 & 22 \\
\hline 20 & 22 & 22 & 22 & 24 & 24 & 23 \\
\hline 25 & 22 & 23 & 23 & 25 & 25 & 24 \\
\hline 30 & 23 & 24 & 23 & 26 & 25 & 24 \\
\hline 35 & 23 & 26 & 24 & 28 & 25 & 25 \\
\hline 40 & 25 & 30 & 25 & 30 & 26 & 27 \\
\hline 45 & 50 & 32 & 35 & 37 & 27 & 36 \\
\hline 50 & 79 & 39 & 54 & 66 & 27 & 53 \\
\hline 55 & 87 & 46 & 71 & 84 & 27 & 63 \\
\hline 60 & 88 & 59 & 87 & 92 & 28 & 71 \\
\hline
\end{tabular}


Table 2. Temperature on the non-exposed side of the sample №2

\begin{tabular}{|c|c|c|c|c|c|c|}
\hline \multirow{2}{*}{$\begin{array}{c}\text { Time, } \\
\text { min }\end{array}$} & \multicolumn{6}{|l|}{ Temperature according to thermoelectric converters on the non-exposed side } \\
& \multicolumn{7}{|c|}{ of the sample №2, ${ }^{\circ} \mathrm{C}$} \\
\hline 0 & 20 & 21 & 21 & 21 & 22 & 21 \\
\hline 5 & 20 & 21 & 21 & 21 & 23 & 21 \\
\hline 10 & 20 & 21 & 22 & 22 & 23 & 22 \\
\hline 15 & 21 & 22 & 22 & 23 & 24 & 22 \\
\hline 20 & 22 & 22 & 23 & 24 & 24 & 23 \\
\hline 25 & 22 & 24 & 23 & 27 & 25 & 24 \\
\hline 30 & 23 & 26 & 23 & 26 & 25 & 25 \\
\hline 35 & 23 & 26 & 24 & 30 & 25 & 26 \\
\hline 40 & 28 & 30 & 29 & 30 & 26 & 29 \\
\hline 45 & 59 & 32 & 39 & 37 & 37 & 41 \\
\hline 50 & 85 & 39 & 54 & 66 & 42 & 57 \\
\hline 55 & 96 & 46 & 71 & 84 & 53 & 70 \\
\hline 60 & 108 & 69 & 87 & 92 & 68 & 85 \\
\hline
\end{tabular}

The authors summary test results are presented in Table 3 .

The test duration was 60 minutes.

Table 3. Summary test results

\begin{tabular}{|c|c|c|c|c|c|}
\hline \multirow{3}{*}{$\begin{array}{l}\text { № } \\
\text { pos }\end{array}$} & \multirow{3}{*}{$\begin{array}{l}\text { Name of } \\
\text { regulatory } \\
\text { document }\end{array}$} & \multirow{3}{*}{$\begin{array}{l}\text { Name of observed } \\
\text { parameter }\end{array}$} & \multicolumn{3}{|c|}{ Parameter value } \\
\hline & & & \multirow[t]{2}{*}{ by the regulatory document } & \multicolumn{2}{|c|}{ Actual } \\
\hline & & & & \begin{tabular}{|c|} 
Specimen \\
№1
\end{tabular} & $\begin{array}{l}\text { Specimen } \\
\text { №2 }\end{array}$ \\
\hline \multirow[t]{4}{*}{1} & \multirow{4}{*}{$\begin{array}{c}\text { par. } 8.1 .2 \\
\text { GOST } \\
30247.1-94\end{array}$} & \multirow[t]{4}{*}{$\begin{array}{l}\text { Loss of bearing capacity } \\
\text { (R): }\end{array}$} & - due to a collapse of the structure; & \multicolumn{2}{|c|}{$\begin{array}{c}\text { have not been } \\
\text { detected }\end{array}$} \\
\hline & & & \multicolumn{3}{|c|}{ - occurrence of critical deflections: } \\
\hline & & & $\begin{array}{c}\text { - if a deflection has reached } \mathrm{L} / 20 \\
\text { i.e. } 20 \mathrm{~cm}\end{array}$ & \multicolumn{2}{|c|}{$\begin{array}{l}\text { have not been } \\
\text { reached }\end{array}$} \\
\hline & & & $\begin{array}{l}\text { - if a deform rate has reached } \\
\mathrm{L}^{2} /(9000 \mathrm{~h}), \text { i.e. } 0,8 \mathrm{~cm} / \mathrm{min}\end{array}$ & \multicolumn{2}{|c|}{$\begin{array}{l}\text { have not been } \\
\text { reached }\end{array}$} \\
\hline \multirow[t]{2}{*}{2} & \multirow[t]{2}{*}{$\begin{array}{c}\text { par. } 8.1 .2 \\
\text { GOST } \\
30247.1-94\end{array}$} & \multirow{2}{*}{$\begin{array}{l}\text { Loss of heat insulating } \\
\text { ability (I) due to } \\
\text { temperature increase on the } \\
\text { unheated surface of the } \\
\text { structure: }\end{array}$} & $\begin{array}{c}\text { - an average of more than } 140{ }^{\circ} \mathrm{C} \\
\text { compared with the surface } \\
\text { temperature of the structure before } \\
\text { testing; }\end{array}$ & \multicolumn{2}{|c|}{$\begin{array}{c}\text { have not been } \\
\text { detected }\end{array}$} \\
\hline & & & $\begin{array}{l}\text { more than } 180^{\circ} \mathrm{C} \text { at any point on } \\
\text { the surface of a structure in } \\
\text { comparison to the temperature of } \\
\text { the surface of the structure before } \\
\text { testing or more than } 220^{\circ} \mathrm{C} \text {, } \\
\text { regardless of the temperature of } \\
\text { the structure before testing }\end{array}$ & \multicolumn{2}{|c|}{$\begin{array}{l}\text { have not been } \\
\text { detected }\end{array}$} \\
\hline 3 & $\begin{array}{c}\text { par. } 8.1 .3 \\
\text { GOST } \\
30247.1-94\end{array}$ & $\begin{array}{l}\text { Loss of integrity (E) as a } \\
\text { result of trough cracks or } \\
\text { holes formation which let } \\
\text { combustion products or } \\
\text { flames trough: }\end{array}$ & $\begin{array}{c}\text { - ignition of a cotton swab for } 10 \mathrm{~s} \\
\text { after presenting to the sample }\end{array}$ & \multicolumn{2}{|c|}{$\begin{array}{c}\text { have not been } \\
\text { detected }\end{array}$} \\
\hline
\end{tabular}




\section{Conclusion}

1. It is shown that monolithic foam concrete filling has a positive effect on the fire resistance of LSCS slab panels and, as a result, on the fire protection of LSGS slab panels when exposed to elevated temperatures. Foam concrete is proposed to be used not only as energy-efficient heat-insulating material but also as a means of increasing the fire resistance of load-bearing structures

2. The actual fire resistance limit of samples of the slab panel fragment is at least RE 60 with a uniformly distributed load $4 \mathrm{kN} / \mathrm{m}^{2}$. During the experiment on the unheated floor surface, the maximum temperature set was $108{ }^{0} \mathrm{C}$ after 60 minutes of temperature exposure. At the same time, the temperature on the heated surface had values of about $1000{ }^{0} \mathrm{C}$. This circumstance confirms the high fire resistance in terms of thermal insulation capacity (I60)

3. The maximum deflection of the samples was $91.2 \mathrm{~mm}$, which does not meet the requirements of rigidity under normal power loads, but meets the requirements of permissible movements under high-temperature exposure (fire tests)

\section{References}

1. Rybakov V., Seliverstov A., Petrov D., Smirnov A., and Volkova A., Lightweight steel concrete structures slab panels load-bearing capacity in MATEC Web of Conferences, Dec. 2018, 245 (2018) doi: 10.1051/matecconf/201824508008.

2. V. A. Rybakov, I.A. Ananeva, E. D. Pichugin, and M. Garifullin, "Heat protective properties of enclosure structure from thin-wall profiles with foamed concrete," Mag. Civ. Eng., 94, № 2, pp. 11-20, (2020), doi: 10.18720/MCE.94.2.

3. D. O. Sovetnikov, N.V. Videnkov, and D. A. Trubina, "Light gauge steel framing in construction of multi-storey buildings," Constr. Unique Build. Struct, vol. 3(30), № 3, pp. 152-165, (2015) doi: 10.18720/CUBS.30.11.

4. N. I. Vatin, V. V. Volodin, Ye. A. Zolotareva, K. V. Petrov, and Ye. N. Zhmarin, Rekonstruktsiya krysh Sankt-Peterburga na osnove legkikh stal'nykh tonkostennykh konstruktsiy i antiobledenitel'noy sistemy, Mag. Civ. Eng., 12, № 2, pp. 59-64, (2010) doi: 10.18720/MCE.12.10.

5. V. Rybakov, A. Seliverstov, D. Petrov, A. Smirnov, and A. Volkova, "Strength characteristics of foam concrete samples with various additives," in MATEC Web of Conferences, Dec. 2018, 245 (2018) doi: 10.1051/matecconf/201824503015.

6. K. Usanova and Y. G. Barabanshchiko, Cold-bonded fly ash aggregate concrete, Mag. Civ. Eng., 95, № 3, pp. 104-118, (2020) doi: 10.18720/MCE.95.10.

7. K. Usanova, Properties of Cold-Bonded Fly Ash Lightweight Aggregate Concretes, in Lecture Notes in Civil Engineering, 70, pp. 507-516, (2020)

8. H. Fares, H. Toutanji, K. Pierce, and A. Noumowé, "Lightweight self-consolidating concrete exposed to elevated temperatures,” J. Mater. Civ. Eng., 27, № 12, (2015), doi: 10.1061/(ASCE)MT.1943-5533.0001285.

9. L. Hou, J. Li, Z. Lu, Y. Niu, J. Jiang, and T. Li, Effect of nanoparticles on foaming agent and the foamed concrete, Constr. Build. Mater, 227, (2019), doi: 10.1016/j.conbuildmat.2019.116698.

10. O. D. Samarin, Temperature in linear elements of enclosing structures, Mag. Civ. Eng., 70, № 2, pp. 3-10, (2017), doi: 10.5862/MCE.70.1.

11. V. A. Rybakov, I. A. Ananeva, A. O. Rodicheva, and O. T. Ogidan, "Stress-strain state of composite reinforced concrete slab elements under fire activity, Mag. Civ. Eng., 74, № 6, pp. 161-174, (2017), doi: 10.18720/MCE.74.13. 
12. E. Nedviga, N. Beresneva, M. Gravit, and A. Blagodatskaya, "Fire Resistance of Prefabricated Monolithic Reinforced Concrete Slabs of Marko' Technology, Adv. Intell. Syst. Comput., 692, pp. 739-749, (2018), doi: 10.1007/978-3-319-70987-1_78.

13. A. V. Bushmanova, D. K. Kharchenko, K. S. Semenov, Y. G. Barabanshchikov, V. K. Korovina, and A. V. Dernakova, Thermal cracking resistance in massive steelreinforced concrete structures, Mag. Civ. Eng., 79, № 3, pp. 45-53, (2018) doi: 10.18720/MCE.79.5.

14. J. J. del Coz-Díaz, J. E. Martínez-Martínez, M. Alonso-Martínez, and F. P. Álvarez Rabanal, Comparative study of LightWeight and Normal Concrete composite slabs behaviour under fire conditions, Eng. Struct., 207, (2020), doi: 10.1016/j.engstruct.2020.110196.

15. C. O. Chin, X. Yang, S. Y. Kong, S. C. Paul, Susilawati, and L. S. Wong, Mechanical and thermal properties of lightweight concrete incorporated with activated carbon as coarse aggregate, J. Build. Eng., 31, (2020) doi: 10.1016/j.jobe.2020.101347.

16. Q. T. Nguyen, T. Ngo, P. Tran, P. Mendis, L. Aye, and S. K. Baduge, Fire resistance of a prefabricated bushfire bunker using aerated concrete panels, Constr. Build. Mater, 174, pp. 410-420, (2018), doi: 10.1016/j.conbuildmat.2018.04.065.

17. X. Wang, P. Ren, and W. Wang, Post-fire mechanical property of thin-walled steel beam-ceramsite concrete assembled composite floors, Jianzhu Jiegou Xuebao/Journal Build. Struct, 38, № 4, pp. 70-80, (2017), doi: 10.14006/j.jzjgxb.2017.04.009.

18. B. Baleshan and M. Mahendran, Experimental study of light gauge steel framing floor systems under fire conditions, Adv. Struct. Eng., 20, № 3, pp. 426-445, (2017), doi: 10.1177/1369433216653508.

19. B. Baleshan and M. Mahendran, Numerical study of high strength LSF floor systems in fire, Thin-Walled Struct., 101, pp. 85-99, (2016), doi: 10.1016/j.tws.2015.12.018.

20. W. H. Wan Badaruzzaman, M. F. M. Zain, H. M. Shodiq, A. M. Akhand, and J. Sahari, Fire resistance performance of profiled steel sheet dry board (PSSDB) flooring panel system, Build. Environ., vol. 38, № 7, pp. 907-912, (2003), doi: 10.1016/S0360-1323(03)00029-5.

21. G. C. Clifton, Design of composite steel floor systems for severe fires, in Proceedings of 8th Pacific Structural Steel Conference - Steel Structures in Natural Hazards, PSSC 2007, 2, pp. 237-242, (2007)

22. H. Gu, X. Wang, and J. Xu, "Fire test on fabricated composite slabs of lightweight aggregate concrete and thin-walled steel beams with openings in web," Jianzhu Jiegou Xuebao/Journal Build. Struct, 37, № 5, pp. 48-56, (2016), doi: 10.14006/j.jzjgxb.2016.05.006.

23. A.V. Bushmanova, D.K. Kharchenko, K.V. Semenov, Yu.G. Barabanshchikov, V.K. Korovina, A.V. Dernakova, Thermal cracking resistance in massive steel-reinforced concrete structures, Magazine of Civil Engineering, 79 (3), pp. 45-53, (2018)

24. M. Gravit, E. Nedviga, N.Vinogradova, Z. Teplova, Fire resistance of prefabricated monolithic slab, MATEC Web of Conferences, 106, article № 02025, (2017) 